\title{
Study and use of genetic potential of lupin for creation of efficient initial selection material and high-yielding varieties
}

\author{
Bardakov V. \\ Institute of Agricultural Microbiology and Agro-industrial Manufacture of the National Academy \\ of Agrarian Sciences of Ukraine
}

The purpose. To study and use genetic potential of lupin in selection operation with the purpose to create new high-yielding varieties. Methods. Field - for phenological observations and biometric measurements; laboratory - for assessment of productivity of the studied material. Results. Collection samples are studied of gene pool of yellow, white and angustifoliate lupin of different ecologicalgeographical parentage by attributes of duration of interphase periods «sprouts-blooming», "bloomingripening» and whole vegetation, productivity and resistance to fusarial wilt on infection background. Conclusions. Sources and donors with attributes of earliness, high productivity and resistance to fusarial wilt are selected. Their use in selection made it possible to create new promising varieties of yellow lupin Zolotyi Kupol and angustifoliate lupin Locomotive.

Key words: lupin, collection sample, earliness, productivity, fusarial wilt.

In the conditions of the Ukrainian Polissia and Forest-steppe, leguminous crops play an important role in reducing fodder protein deficiency, among which lupine fodder is promising. Getting the highest collection of high quality protein per unit area and, at the same time, greatly improving the soil fertility is possible by growing lupine yellow on green food and silage, white and lupine white lupine, mainly on grains.

In the grain of feed varieties of lupine contains $30-52 \%$ protein, in dry matter of green mass - $18-20 \%$ $[1,2,3]$. In addition, in the grain of narrow-leaved and white lupine contains $6.2-12.0 \%$ of oil $[4,5,6]$.

The composition of the protein of lupine includes almost all essential amino acids, so the biological value of lupine protein is closer to the most valuable protein of soy. Taking this into account, the green mass of lupine is a good feed for animals both in fresh form and in silage, and grain is a good component for the production of high quality fodder balanced by protein and amino acids. It is also important that the grain of lupine does not require heat treatment, in addition to simple grinding to the dermis, because it has significantly less inhibitors of proteases, hemagglutinins, and others.

Culture of lupine is the best means of energy and resource conservation in agriculture and the preservation of the environment. This is due to its ability to absorb biologically pure nitrogen from the air, and phosphorus - from the hardly soluble compounds of the arable and subterraneous layers of soil, which leads to the economical use of expensive mineral fertilizers. With satisfactory yield, lupine plants absorb $135-228 \mathrm{~kg} / \mathrm{ha}$ of nitrogen from the air $[7,8]$, a significant part of its $50-150 \mathrm{~kg} /$ ha remains in the soil and is almost completely used by plants of subsequent crop rotation crops, which contributes to increasing their yield.

Despite the high quality and high potential of lupine, its use in production is limited.

In order to overcome this state in lupines, the primary importance belongs to the varietal composition of culture. To the State register of plant varieties, suitable for distribution in Ukraine, by the year 2017, 10 varieties of white lupine, 7 yellow and 4 pericarp are entered [9]. However, they still do not sufficiently meet the requirements of agricultural production (are affected by diseases, have an extended vegetation period, etc.). Therefore, the actual value in increasing the yield of lupine is to create new, adaptive varieties with a comprehensive combination of economic and valuable features and their implementation in production.

The effectiveness of breeding work with fodder lupine largely depends on the development of valuable initial selection material, the bulk of which is created by intrinsic hybridization. Therefore, special attention 
in the selection process is drawn to the study of collection patterns of various ecological and geographical origin, used as parental forms - sources and donors of valuable economic characteristics. The the Institute of Agricultural Microbiology and Agro-industrial Manufacture of the National Academy of Agrarian Sciences of Ukraine has collected a large collection of lupine with various features, which today has 650 samples of five species from more than 20 countries of the world. All collection samples are certified, registered and registered at the National Center for Plant Genetic Resources of Ukraine base (certificate number 11, dated 17.11.2005) and a certificate (certificate number 57, dated 23.12.2008) of the collection of lupine. Each year, studies are conducted to study the collection of lupine gene pool to identify sources and donors of key economic and valuable features in order to attract them to hybridization. In the process of study, attention is drawn to such basic features as the duration of periods "sprouts - blooming", "blooming - maturing" and entire vegetation periods, disease, seed yield, plant height.

The purpose of the research is to study and use the genetic potential of lupine fodder in breeding work to create new high-yielding varieties with high adaptive properties.

Materials and methods of research. During the research, 350 collections of lupine (65 white lupine, 250 yellow and 35 narrow-leafed lupine) domestic and foreign origin (Belarus, Russia, Germany, Poland, and others) were used. The research was conducted during 2011-2016 at the experimental field of the scientific support of agricultural production ISMAV NAAN on the common and infectious fusarium background. Field tests [10] and laboratory methods were used. Single-row plots with an area of $1.8 \mathrm{~m}^{2}$, repetition of 2-time, standard-quality varieties were sown through every 20 plots. A comparative estimation was made for the morphological and basic economic-valuable features. Phenological observations were carried out in accordance with the methodology of the State Commission on the sorting trial of s.-g. Cultures [11]. Influence of fusariosis and anthracnosis on the method of Korniychuk M.S. [12] and Kirika N.N. And Beznoshenko V.P. [13]. The yield structure was determined by the method of a test sheaf. Qualitative determination of alkaloids in seeds - using Bukhard reagent (iodine solution in iodine potassium).

Research results. 350 collections of samples were studied, including Yellow lupine - 250, white lupine - 65 and narrow-leafed lupine - 35.

The analysis of the data of the conducted phenological observations in the years of research in the conditions of the Left Bank Polissya showed a significant differentiation of the collection samples of lupine for the duration of the growing season, fluctuating within $78-145$ days. According to the international classifier of the genus Lupinus L. (1983), the collection of lupine yellow for the duration of the vegetation period was divided into five groups of maturation (Figure 1), white lupine for four (Figure 2), and all samples of narrow lupine are characterized as ultra-fast (2nd group of ripeness). 


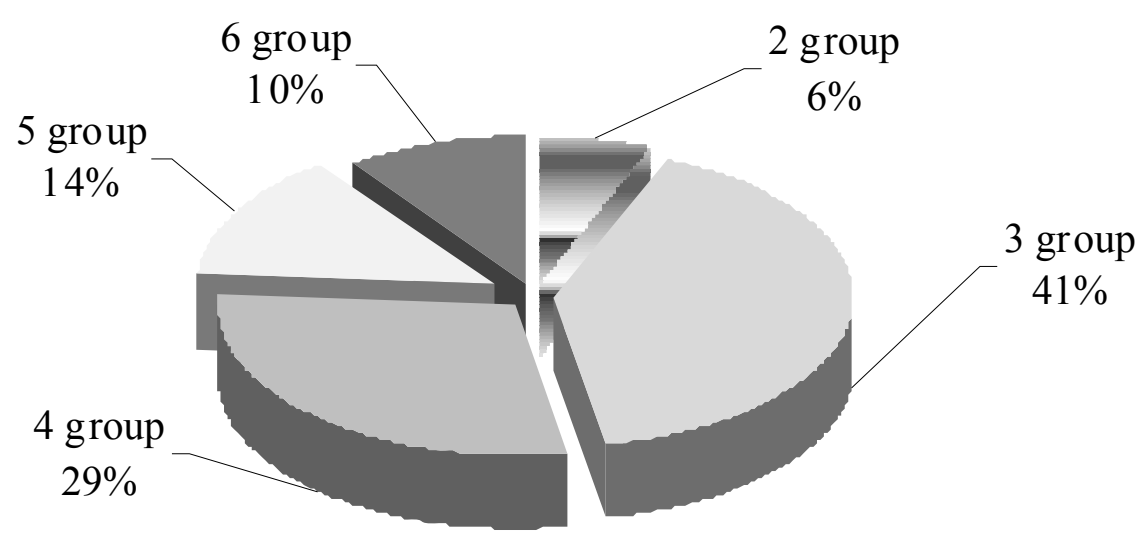
$\equiv 2$ group -very early (vegetative period $71-100$ days) -15 samples
3 group - super early (101-115 days) - 103 samples
4 group - early (116-125 days ) - 72 samples
5 group - mid-ripening (126-135 days) - 35 samples
6 group - mid-late (136-145 days) - 25 samples

Fig. 1. The value of the collections of lupine yellow samples according to the length of their growing season.

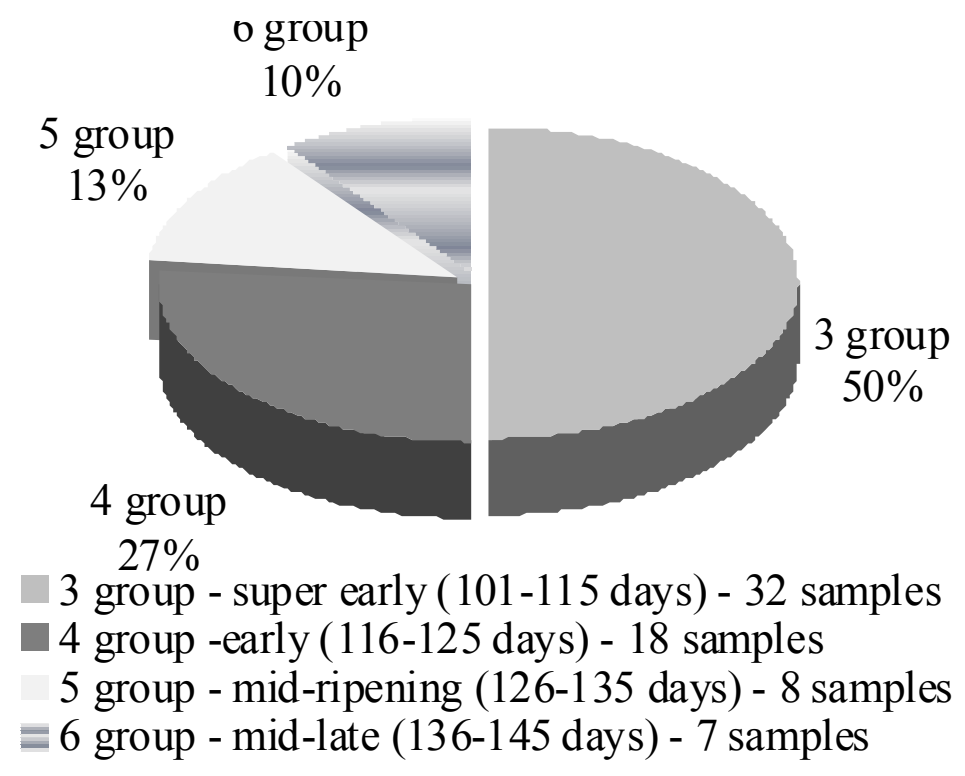

Fig. 2. The value of the white lupine collection samples according to the length of their growing season.

The vegetative period in lupine can be divided into two main parts - the period before flowering, when the formation and growth of vegetative organs occurs, and from flowering to maturing, when the seeds are formed and matured. The greatest interest in the selection practice of forage lupine is the phase-shift period of flowering, since it is less dependent on environmental conditions. The results of our studies confirm the opinion of many scholars who suggest an assessment of the velocity to be carried out during the flowering period, as there is a strong correlation between the duration of the growing season as a whole and the period of the flowering-laden season $(r=0,720-0,897)$ [14].

In order to identify sources and donors of the signs of rapidity in the final research, we have identified samples that on average over the years of research were characterized by a short period of sprouts blooming. Among the collections studied, with the shortest first development period of up to 44 days in 
yellow lupine and 40 days in white, 28 and 14 numbers respectively, and 6 samples of lupine, with a duration of this period up to 36 days, were allocated respectively.

As sources of rapidity in the selection of lupine, collectible specimens should be used: yellow lupine Epigonal 40/92 (No. National Catalog UD0800523), Demidovsky (UD0801476), Bryansk 81 (UD0800037), p.645 (UD0800157), Academic 1 x Stodolishchensky (UD0800259), Epigonal Ultra (UD0800303), Hybrid 1135 (UD0800121), Line 7486 (UD0801237), Line 7521 (UD0801226) and Line 7833 (UD0801384); White lupine - Deter 1 (UD0800533), Gamma (UD0800535), Delta (UD0800534), August (UD0801481), line 6871 (UD0800475), line 6868 (UD0800494); The lupine of the pericarp is Primchaatsvet (UD0800543), Pralesk (UD0801250), K-UA-1 (UD0801470), Mitan (UD0801252), BGB-1 (UD0801467) and K-Lowalk (UD0801469).

In order to determine the stability of collection samples lupine against Fusarium wilt (Fusarium oxysporum), all the material that has been studied for infectious Fusarium background, which was established in 1983, where lupine crop is grown. Among the samples that had a steady weakness of the disease (up to 10\%) throughout the period of research, we have allocated 15 forms of lupine yellow, 8 white and 11 - narrow-leafed. As a source of resistance to Fusarium wilt recommend using a selection samples: yellow lupine - ultra Epihonalnyy (UD0800303), line 7922 (UD0801522), line 8095 (UD0801665), Jari (UD0801637) (Origin Ukraine) Dyemidovskiy (UD0801476) ( Russia), G-218 (UD0800049) (USA), Pauelsen Gelbe (UD0800096), Neven (UD0800045) (Germany), etc.; lupine white Lybed (UD0800013), Fog (UD0800011), September (UD08 00010) Line 7011 (UD0800132), line 6868 (UD0800494), line 7607 (UD0801260), line 7456 (UD0800531) (Ukraine) and Delta (UD0800534) (Russia); Lupine of the pericarp - Pershatsvet (UD0800543), Zhozzinski (UD0801568), Mitan (UD0801252) (Belarus), SN 11/02 (UD0801670), SN 11/03 (UD0801671), S.N.13 / 01 (UD0801723), KUA-1 (UD0801470), D-UA-1 (UD0801468), Pelican (UD0801516) (Ukraine), Byelozornyy 110 (UD0801442) Siderat 38 (UD0801259) (Russia).

It should be noted that most resistant to fusariose samples have a relatively short period of vegetation.

The study of samples of the lupine gene pool for resistance to anthracnose pathogen (Colletotrichum gloeosporioides) was performed on a normal background. Unfortunately during epiphytotic significant development of anthracnose virtually all collection specimens yellow lupine and white reached $50-90 \%$ and we could not provide any form, characterized by a genetic resistance to this dangerous disease. The lupine narrow-necked specimens exhibited significantly greater resistance to anthrax, compared to other species, and the disease was $10-19 \%$. Apparently this can be explained by the greater genetic stability of this type of lupine against the disease.

On the basis of generalized yield data, for the entire period of research, we have identified 34 most productive collections of lupine.

Thus, samples of the following are characterized by high productivity $\left(220 \mathrm{~g} / \mathrm{m}^{2}\right.$ or more in yellow and $300 \mathrm{~g} / \mathrm{m}^{2}$ or more in white lupine): yellow lupine - R.I.274830 (UD0800181) from USA, Torch (UD0800234), hibryd 7 / 76m (UD0800362), hibryd 282m (UD0800366), line 8095 (UD0801665), line 7922 (UD0801522), Jari (UD0801645) (all native origin) and others; White Lupine - Generous 50 (UD0801517), Rhapsody (UD0801663), September (UD0800010) (All Ukraine), Gamma (UD0800535) from Russia and others.

Among the lupine samples of the narrow-leaf, as a source on the basis of productivity in breeding programs, it is recommended to use: Lokomotyv (UD0801724), SN 11/01 (UD0801669), SN 11/03 (UD0801671), K-UA-1 (UD0801470) (all Ukraine), Pershatsvet (UD0800543) (Belarus) and others that are on average over the years of research in the zone conditions Polissia provided the highest seed yield per unit area $\left(190-220 \mathrm{~g} / \mathrm{m}^{2}\right)$.

All collected information about samples in the base and reference collections is in electronic form, which allows the user at any time to have an operational access to the data, the possibility to organize or group the collection material according to the level of the manifestation of a particular sign, or a set of features, as well as If necessary, replenish new data on the gene pool. 
Dedicated sources and donors of economic and valuable features among collections of lupine, as well as breeding lines created at the institute, are constantly involved in the selection process.

As a result of this work, new types of lupine yellow golden dome (application No. 15402002) and lupine of the narrow-leaved Locomotive (application No. 13403002) were created and transferred to the state variety trial. The varieties provide seed yields of 2.5-3.0 t/ha, and the green mass is $50.0-43.0 \mathrm{t} / \mathrm{ha}$, respectively. Early-emerging, growing season - 95-105 days, protein content in grain 33-38\%, alkaloids content - 0,028-0,032\%, resistant to fusariose and drought.

\section{Conclusions}

In the conditions of the Left Bank of Ukrainian Polissia for the first time extensive study of the gene pool of lupine yellow, white and narrow-haired of various ecological and geographical origin on the main economic and valuable features. Sources and donors with signs of early onset, high productivity and resistance to fusariose, information contained in the base and reference collections of the gene pool of lupine, created at the Institute of Agricultural Microbiology and Agro-Industrial Production of the National Academy of Sciences of Ukraine, were identified.

Using selected collection samples in the breeding process, new promising lupine varieties of the yellow Zolotyj kupol and lupine of the narrow-leaved Lokomotyv, characterized by high seed and green weight productivity, early maturity, resistance to fusariose and drought, were created.

\section{Bibliography}

1. Alekseev E.K. (1968). Odnoletnie kormovye lyupiny. Moskva: Kolos. $263 \mathrm{~s}$.

2. Domash V.I., Rogul'chenko I.V., Busnyuk V.O., Ermolickaya L.V., Mironenko A.V. (2001). Belki semyan lyupina $\mathrm{i}$ ih fiziko-himicheskie svojstva. Tez. dokl. mezhdunarodnoj nauchno-prakticheskoj konferencii (VNII lyupina). Bryansk. -S. 38-41.

3. Majsuryan N.A., Atabekova A.I. (1974). Lyupin. Moskva: Kolos. $462 \mathrm{~s}$.

4. Golovchenko O.V., Fartushnyak A.T., Kucherenko V.G., Kucherenko N.M. (2001). Perspektivy i napravleniya selekcii i semenovodstva belogo lyupina na Ukraine. Tez. dokl. mezhdunarodnoj nauchnoprakticheskoj konferencii (VNII lyupina). Bryansk. S.84-86.

5. Korovina L.M., Mamaeva M.V. (2009). Zhirnokislyj sostav lipidov zerna razlichnyh sortov uzkolistogo lyupina. Tez. dokl. mezhdunarodnoj nauchno-prakticheskoj konferencii (VNII lyupina). Bryansk. S. 211-213.

6. Kurlovich B.S. (2002). Lupins (Geography, classification, genetic resources and breeding). OY International North Express. St. Petersburg, Russia. Pellosniemi, Finland. 468 p.

7. Burlachuk V.M. (1974). Izuchenie produktivnosti azotfiksacii rasteniyami lyupina v polevyh usloviyah. Selekciya, semenovodstvo i priemy vozdelyvaniya lyupina. Orel. S. 99-104.

8. Takunov I.P. (1996). Lyupin v zemledelii Rossii. Bryansk: Pridesen'e. $372 \mathrm{s.}$

9. Derzhavnij reestr sortiv roslin, pridatnih do poshirennya v Ukraïni na 2017 rik. Kyiv, 2017. $390 \mathrm{~s}$.

10. Dospekhov B.A. (1985). Metodika polevogo opyta. Moskva: Agropromizdat. $356 \mathrm{~s}$.

11. Metodika derzhavnogo sortoviprobuvannya sil's'kogospodars'kih olijnih, tekhnichnih, pryadivnih ta kormovih kul'tur. Derzh. komisiya Ukraïni po viprobuvannyu ta ohoroni sortiv roslin. - Kyiv: Alefa, 2001. Vip. 3. - S. 61-74.

12. Kornejchuk N.S. (2010). Gribnye bolezni lyupinov: monografiya. Kyiv: Kolobig. 376 s.

13. Kirik N.N., Beznoshchenko V.P. (1993). Ob ocenke ustojchivosti sortov lyupina $\mathrm{k}$ antraknozu. Selekciya i semenovodstvo. № 3. S.42.

14. Bardakov V.A. (2007). Stvorennya i vikoristannya v selekciï genofondu lyupinu zhovtogo za oznakami rann'ostiglosti ta fuzariozostijkosti: avtoref. dis. na zdobuttya nauk. stupenya kand. s.-g. nauk. Kyiv. $21 \mathrm{~s}$. 